medRxiv preprint doi: https://doi.org/10.1101/2020.11.08.20224915; this version posted August 29, 2021. The copyright holder for this preprint (which was not certified by peer review) is the author/funder, who has granted medRxiv a license to display the preprint in perpetuity. It is made available under a CC-BY-NC 4.0 International license .

\title{
State- and County-Level COVID-19 Public Health Orders in California: Constructing a Dataset and Describing Their Timing, Content, and Stricture
}

\author{
Jeremy D. Goldhaber-Fiebert (1), Alexander F. Holsinger (1,2), Erin Holsinger (1), Elizabeth Long
} (1) on behalf of the SC-COSMO Modeling Consortium

July 29,2021

(1) Stanford Health Policy, Centers for Health Policy and Primary Care and Outcomes Research, Stanford University School of Medicine and the Freeman Spogli Institute of International Studies, Stanford, CA, USA

(2) University of Texas at Austin, Austin, TX, USA

\begin{abstract}
Without vaccines, non-pharmaceutical interventions have been the most widely used approach to controlling the spread of COVID-19 epidemics. Various jurisdictions have implemented public health orders as a means of reducing effective contacts and controlling their local epidemics. Multiple studies have examined the effectiveness of various orders (e.g. use of face masks) for epidemic control. However, orders occur at different timings across jurisdictions and some orders on the same topic are stricter than others. We constructed a county-level longitudinal data set of more than 2,400 public health orders issues by California and its 58 counties pertaining to its 40 million residents. First, we describe methods used to construct the dataset that enables the characterization of the evolution over time of California state- and countylevel public health orders dealing with COVID-19 from January 1, 2020 through June 30, 2021. Public health orders are both an interesting and important outcome in their own right and also a key input into analyses looking at how such orders may impact COVID-19 epidemics. To construct the dataset, we developed and executed a search strategy to identify COVID-19 public health orders over this time period for all relevant jurisdictions. We characterized each identified public health order in terms of the timing of when it was announced, went into effect and (potentially) expired. We also adapted an existing schema to describe the topic(s) each public health order dealt with and the level of stricture each imposed, applying it to all identified orders. Finally, as an initial assessment, we examined the patterns of public health orders with in and across counties, focusing on the timing of orders, the rate of increase and decrease in stricture, and on variation and convergence of orders within regions.

\section{Public Availability}

We are making the dataset publicly available as part of our commitment to open data and combating the COVID-19 pandemic (http:// sc-cosmo.org). We intend to update the dataset at least monthly. We are hopeful that others will use our methodological approach to characterize county-level or even city-level public health orders over time across additional states and would be happy to discuss this further via email (jeremygf@stanford.edu). A description of the contents and linkages of released files are provided in Appendix Table 1.
\end{abstract}

\section{Public Health Order Searches}


medRxiv preprint doi: https://doi.org/10.1101/2020.11.08.20224915; this version posted August 29, 2021. The copyright holder for this preprint (which was not certified by peer review) is the author/funder, who has granted medRxiv a license to display the preprint in perpetuity. It is made available under a CC-BY-NC 4.0 International license .

We developed and executed a search strategy to identify COVID-19 public health orders over the analytic time period applied to all California counties and the state itself. We identified website(s) for each county on which public health orders were released and supplemented this with web searches for press releases and media that combined county name, terms relating to COVID-19, and terms relating to public health orders and the topics they dealt with [1-59] (see also Appendix Tables 2 and 3). Search terms used in Google included combinations of each county's name and any of the following: declares emergency; bans gatherings; closes March; reopens April; reopens May; reopens June; Stage 2; Stage 3; recloses July; face coverings.

We recorded URLS and the date that each document was accessed, also archiving documents whenever possible. As some counties maintain only their most recent public health order on their websites (e.g., Solano County), we used the Wayback Machine to examine the orders contained on each such website at all points in time at which orders were added or changed [60]. In addition to gathering county public health orders, we also searched for and compiled the timing and topics of state-level public health guidance that applied to some or all of counties (e.g., all counties in the state, counties on a watch list, etc.) as this sometimes, explicitly or implicitly, substituted for or superseded county orders. Finally, when we encountered them, we separately noted instances where other county ordinances and orders may have related to COVID-19 but were not explicitly public health orders; we used this last category of information for narrative purposes only, excluding it from our dataset and analyses described below as we could not be sure that our search strategy would systematically identifying them in an equivalent way across time and counties.

\section{Characteristic Extraction}

All public health orders and guidance had the following characteristics: 1) county(s) to which they pertained; 2 ) date of announcement; 3) date of effect; and 4) date of expiry ${ }^{1}$ (which could be either an explicit date or ongoing).

\section{Classification of Public Health Order Topics}

We began the schema for order classification using topics found in the COVID-19 US State Policy Database [61]. To these, we added 5 topics to reflect more thoroughly the actions found in the California county public health orders: moratorium on gatherings; quarantine for residents; and lab reporting \& contact tracing; characterization of social bubbling; and details of private events. With the introduction of vaccines to California in December 2020, we split appropriate measures into those for vaccinated and unvaccinated individuals. The complete list of topics and their general definition are provided in Appendix Table 4. Based on full textual review by a study investigator, we classified each identified public health order as to whether it pertained to each of the 16 main topics (e.g., face masks, gathering size, etc.). In the event of ambiguity of whether an order dealt with a given topic, a second study investigator reviewed the text and discussion to reach consensus was used to reach a final determination. $A$

\footnotetext{
${ }^{1}$ Expiry dates were mainly used by counties in the beginning of the COVID-19 epidemic and were typically overwritten by additional orders before their expiration.
} 
medRxiv preprint doi: https://doi.org/10.1101/2020.11.08.20224915; this version posted August 29, 2021. The copyright holder for this preprint (which was not certified by peer review) is the author/funder, who has granted medRxiv a license to display the preprint in perpetuity. It is made available under a CC-BY-NC 4.0 International license .

composite category of current level of county closure was added to the list which combined initial closures, reopenings, and reclosures (see below for further detail).

\section{Classification of Stricture on Each Public Health Order Topic}

The primary focus of the classification of stricture was to gauge how public health orders relating to specific topics became more or less strict within each county over time. For example, instead of attempting to rank whether closure of indoor dining in a given county was more or less strict than closure of nail salons in another county, we focused on how the set of business types that were closed in a given county widened or narrowed over time. For certain topic areas (e.g., state of emergency), stricture was binary - whether an order about it existed at a given point in time or not. For others, stricture had ordinality (e.g., the increasing number of people allowed at gatherings or events). In addition to applying a within-county numeric scale, specific free text information was extracted to capture the details of how the order's stricture on a given topic was determined. Lists of scales and their definitions are provided in Appendix Table 5. Based upon the scales we used, a study investigator classified the strictness of each order for each category it pertained to. Again, in the event of ambiguity, a second study investigator reviewed and discussed the particular example until consensus was reached. Since public health orders dealt with closures, reopenings, and reclosures, we constructed a combined variable on current strictness of closure/openness (which essentially added closure, reopening, and reclosure with a floor of 0 for completely open to account for differences in the ordinal scales we used). The main determinant of this variable's value became the state-level tiered system upon the system's rollout on August $31^{\text {st }}$ with the exception that counties could opt to remain more strictly closed than the state system required [62].

The use of expiration dates issued with each order varies by order topic. Topics related to opening and closing, for example, physical distancing, stay at home, reopening, reclosing, and social bubbles tended to have expiration dates issued with orders. In many cases the orders were superseded by new orders prior to the expiration dates, but expiration dates are honored for these orders if they were not superseded. These expirations explain the numerous changes to closure and stay at home levels in January, despite the low number of orders for the month. Lab and contact tracing, mask restrictions, and quarantine restrictions tended to not have expiration dates published with the orders and are therefore only modified in the data if they have a new order that specifically increases or decreases the stricture of the previous order.

\section{Descriptive Analysis of Public Health Orders and Their Topics and Stricture}

We identified and characterized 2,457 state- and county-level public health orders related to COVID-19 that were issued and became effective between January 1, 2020 and June 30, 2021. Of those, 2,268 dealt with the key topics of physical distancing, stay at home, gatherings for unvaccinated individuals, gatherings for fully vaccinated individuals, private events for unvaccinated individuals, private events for fully vaccinated individuals, quarantine instructions for unvaccinated residents, quarantine instructions for fully vaccinated residents, quarantine instructions for unvaccinated visitors, quarantine instructions for fully vaccinated visitors, 
medRxiv preprint doi: https://doi.org/10.1101/2020.11.08.20224915; this version posted August 29, 2021. The copyright holder for this preprint (which was not certified by peer review) is the author/funder, who has granted medRxiv a license to display the preprint in perpetuity.

It is made available under a CC-BY-NC 4.0 International license .

reopening, reclosing, lab and contact tracing, mask restrictions, social bubbles for unvaccinated households, and social bubbles for fully vaccinated households $s^{2,3,4}$.

Counts of orders: For the date ranges reviewed, we determined the number of COVID-19 public health orders promulgated. The months with the largest numbers of orders corresponded to rises in detected case rates.

Table 1: Number of orders by month

\begin{tabular}{|l|l|}
\hline Month & Number of distinct orders \\
\hline January & 3 \\
\hline February & 5 \\
\hline March & 273 \\
\hline April & 154 \\
\hline May & 239 \\
\hline June & 221 \\
\hline July & 223 \\
\hline August & 98 \\
\hline September & 74 \\
\hline October & 120 \\
\hline November & 207 \\
\hline December & 118 \\
\hline January & 32 \\
\hline February & 41 \\
\hline March & 93 \\
\hline April & 132 \\
\hline May & 146 \\
\hline June & 89 \\
\hline
\end{tabular}

Counts of topics covered by orders: For the date ranges reviewed, we determined the number of order-topics (i.e., each time any COVID-19 public health order dealt with a given topic). Like counts of orders, we treated the topics covered by state guidance and orders in two ways: including them as a county orders when relevant or excluding them. We also calculated the

\footnotetext{
${ }^{2}$ The topic of social bubbles, i.e., the number of individuals that your household can interact with, was introduced for the November $30^{\text {th }}$ data release based on new orders being issued on this topic.

${ }^{3}$ The topics of quarantine for fully vaccinated residents, quarantine for fully vaccinated visitors, and social bubbles for vaccinated households were introduced for the May $3^{\text {rd }}$ data release based on new orders being issued on these topics. The original topics changed to quarantine instructions for unvaccinated individuals and households. The values for social bubbles for unvaccinated households were expanded to reflect guidance that allowed an additional fully vaccinated household to join social bubbles - more details on the values can be found in Appendix Table 5.

${ }^{4}$ The topics of private events for unvaccinated and for fully vaccinated individuals were introduced with the June $7^{\text {th }}$ data release based on new orders being issued on these topics. Additionally, the original topic of gatherings became gatherings for unvaccinated individuals and a new topic of gatherings for fully vaccinated individuals was introduced with the June $7^{\text {th }}$ data release.
} 
medRxiv preprint doi: https://doi.org/10.1101/2020.11.08.20224915; this version posted August 29, 2021. The copyright holder for this preprint (which was not certified by peer review) is the author/funder, who has granted medRxiv a license to display the preprint in perpetuity.

It is made available under a CC-BY-NC 4.0 International license .

percent of each specific order type as a function of total orders. Since some orders dealt with multiple topics in a single order, the percentages sum to greater than one. A large fraction of orders dealt with which venues would be open or closed and/or the levels of their closure/openness.

Table 2: Number of orders by topic and percent of orders by topic

\begin{tabular}{|l|r|r|}
\hline Topic & $\begin{array}{r}\text { Number of } \\
\text { orders }\end{array}$ & $\begin{array}{r}\text { Percent of orders } \\
\text { related to topic }\end{array}$ \\
\hline Gatherings for unvaccinated individuals & 218 & $9.6 \%$ \\
\hline Gatherings for fully vaccinated individuals & 158 & $7.0 \%$ \\
\hline Private events for unvaccinated individuals & 158 & $7.0 \%$ \\
\hline Private events for fully vaccinated individuals & 158 & $7.0 \%$ \\
\hline Physical distancing & 239 & $10.5 \%$ \\
\hline Stay at home & 353 & $15.6 \%$ \\
\hline Quarantine for unvaccinated residents & 241 & $10.6 \%$ \\
\hline Quarantine for fully vaccinated residents & 47 & $2.1 \%$ \\
\hline Quarantine for unvaccinated visitors & 47 & $2.1 \%$ \\
\hline Quarantine for fully vaccinated visitors & 29 & $1.3 \%$ \\
\hline Reopening & 926 & $40.8 \%$ \\
\hline Reclosing & 201 & $8.9 \%$ \\
\hline Lab and contact tracing & 94 & $4.1 \%$ \\
\hline Mask restrictions for unvaccinated individuals & 470 & $20.7 \%$ \\
\hline Mask restrictions for vaccinated individuals & 200 & $8.8 \%$ \\
\hline Social bubbles for unvaccinated households & 545 & $24.0 \%$ \\
\hline Social bubbles for fully vaccinated households & 189 & $8.3 \%$ \\
\hline
\end{tabular}

Counts of orders by county: For the date ranges reviewed, we determined the number of COVID-19 public health orders promulgated by each county and examined the distribution of these counts across counties. Since state guidance and orders could substitute for or supersede county orders, we generated county-level counts and other descriptive statistics in two ways, including relevant state orders as a county order when it applied and excluding state orders in counts if they did not apply.

Table 3: Number of orders by county by month

\begin{tabular}{|l|c|c|c|c|c|c|c|c|c|c|c|c|c|c|c|c}
\hline County & Mar & Apr & May & Jun & Jul & Aug & Sep & Oct & Nov & Dec & Jan & Feb & Mar & Apr & May & Jun \\
\hline Alameda & 7 & 4 & 2 & 3 & 6 & 2 & 2 & 5 & 5 & 2 & 1 & 2 & 2 & 2 & 2 & 3 \\
\hline Alpine & 6 & 1 & 2 & 5 & 1 & 1 & 0 & 1 & 4 & 1 & 0 & 1 & 2 & 3 & 2 & 1 \\
\hline Amador & 7 & 2 & 7 & 3 & 1 & 4 & 2 & 1 & 3 & 2 & 2 & 0 & 1 & 2 & 3 & 1 \\
\hline Butte & 3 & 1 & 4 & 3 & 2 & 1 & 2 & 2 & 4 & 3 & 0 & 1 & 2 & 2 & 2 & 1 \\
\hline Calaveras & 3 & 1 & 4 & 3 & 1 & 2 & 1 & 2 & 5 & 2 & 1 & 0 & 1 & 2 & 2 & 1 \\
\hline Colusa & 1 & 0 & 4 & 2 & 3 & 2 & 1 & 2 & 5 & 1 & 2 & 0 & 3 & 1 & 2 & 1 \\
\hline Contra Costa & 7 & 2 & 4 & 4 & 8 & 1 & 4 & 3 & 6 & 3 & 1 & 1 & 2 & 3 & 2 & 1 \\
\hline Del Norte & 6 & 2 & 3 & 6 & 3 & 1 & 0 & 1 & 4 & 1 & 1 & 1 & 0 & 1 & 3 & 1 \\
\hline
\end{tabular}




\begin{tabular}{|c|c|c|c|c|c|c|c|c|c|c|c|c|c|c|c|c|}
\hline El Dorado & 4 & 2 & 3 & 3 & 1 & 1 & 1 & 1 & 5 & 3 & 0 & 0 & 1 & 4 & 2 & 1 \\
\hline Fresno & 2 & 1 & 5 & 4 & 5 & 1 & 2 & 1 & 4 & 1 & 0 & 1 & 1 & 3 & 2 & 1 \\
\hline Glenn & 4 & 0 & 2 & 5 & 4 & 2 & 1 & 2 & 4 & 1 & 0 & 0 & 1 & 2 & 2 & 1 \\
\hline Humboldt & 3 & 1 & 3 & 4 & 1 & 2 & 1 & 3 & 3 & 2 & 1 & 2 & 2 & 3 & 2 & 2 \\
\hline Imperial & 2 & 1 & 4 & 5 & 6 & 2 & 1 & 3 & 2 & 2 & 0 & 1 & 3 & 3 & 2 & 2 \\
\hline Inyo & 4 & 3 & 6 & 3 & 2 & 2 & 1 & 2 & 2 & 2 & 1 & 0 & 0 & 2 & 4 & 1 \\
\hline Kern & 3 & 3 & 2 & 4 & 3 & 1 & 1 & 2 & 4 & 1 & 0 & 0 & 1 & 2 & 2 & 1 \\
\hline Kings & 4 & 1 & 3 & 4 & 6 & 1 & 1 & 2 & 4 & 3 & 0 & 0 & 1 & 2 & 2 & 1 \\
\hline Lake & 9 & 7 & 5 & 4 & 2 & 1 & 0 & 2 & 3 & 1 & 1 & 0 & 1 & 3 & 2 & 1 \\
\hline Lassen & 2 & 3 & 5 & 3 & 1 & 1 & 1 & 1 & 3 & 1 & 1 & 0 & 2 & 2 & 2 & 1 \\
\hline Los Angeles & 9 & 3 & 6 & 6 & 8 & 1 & 2 & 7 & 4 & 3 & 2 & 3 & 2 & 5 & 2 & 3 \\
\hline Madera & 3 & 2 & 2 & 5 & 5 & 1 & 1 & 1 & 2 & 2 & 0 & 0 & 1 & 2 & 3 & 1 \\
\hline Marin & 8 & 2 & 6 & 5 & 5 & 2 & 1 & 3 & 3 & 3 & 0 & 1 & 1 & 3 & 2 & 3 \\
\hline Mariposa & 4 & 3 & 3 & 3 & 1 & 3 & 2 & 1 & 4 & 3 & 1 & 0 & 1 & 2 & 3 & 1 \\
\hline Mendocino & 5 & 4 & 4 & 3 & 5 & 4 & 2 & 3 & 4 & 3 & 1 & 0 & 3 & 5 & 3 & 4 \\
\hline Merced & 3 & 5 & 2 & 3 & 7 & 2 & 1 & 2 & 3 & 1 & 0 & 1 & 1 & 3 & 3 & 1 \\
\hline Modoc & 3 & 0 & 3 & 3 & 4 & 2 & 0 & 1 & 5 & 1 & 1 & 0 & 3 & 3 & 2 & 1 \\
\hline Mono & 5 & 3 & 6 & 4 & 6 & 2 & 1 & 2 & 1 & 4 & 3 & 0 & 2 & 4 & 3 & 1 \\
\hline Monterey & 2 & 3 & 4 & 4 & 4 & 1 & 1 & 1 & 1 & 3 & 0 & 0 & 1 & 3 & 3 & 2 \\
\hline Napa & 5 & 2 & 3 & 7 & 5 & 1 & 0 & 1 & 3 & 2 & 0 & 0 & 2 & 2 & 2 & 2 \\
\hline Nevada & 4 & 5 & 4 & 3 & 3 & 1 & 1 & 1 & 4 & 2 & 0 & 1 & 2 & 2 & 2 & 2 \\
\hline Orange & 4 & 3 & 4 & 4 & 6 & 1 & 1 & 1 & 5 & 2 & 0 & 0 & 3 & 1 & 3 & 2 \\
\hline Placer & 6 & 3 & 4 & 3 & 2 & 1 & 1 & 2 & 5 & 3 & 0 & 1 & 1 & 2 & 4 & 1 \\
\hline Plumas & 1 & 1 & 5 & 4 & 1 & 1 & 0 & 2 & 5 & 2 & 1 & 1 & 1 & 2 & 2 & 1 \\
\hline Riverside & 10 & 9 & 5 & 4 & 5 & 1 & 1 & 2 & 2 & 1 & 0 & 0 & 1 & 2 & 2 & 1 \\
\hline Sacramento & 3 & 1 & 3 & 4 & 4 & 4 & 3 & 2 & 4 & 2 & 2 & 2 & 5 & 3 & 2 & 3 \\
\hline San Benito & 4 & 2 & 3 & 3 & 4 & 1 & 1 & 2 & 4 & 1 & 0 & 0 & 1 & 2 & 2 & 2 \\
\hline $\begin{array}{l}\text { San } \\
\text { Bernardino }\end{array}$ & 6 & 5 & 4 & 1 & 5 & 1 & 1 & 1 & 2 & 1 & 0 & 1 & 2 & 3 & 2 & 1 \\
\hline San Diego & 7 & 5 & 4 & 4 & 7 & 3 & 1 & 1 & 3 & 3 & 1 & 3 & 1 & 2 & 3 & 3 \\
\hline $\begin{array}{l}\text { San } \\
\text { Francisco }\end{array}$ & 10 & 3 & 5 & 5 & 6 & 2 & 5 & 6 & 4 & 7 & 2 & 2 & 2 & 2 & 3 & 2 \\
\hline San Joaquin & 8 & 4 & 5 & 4 & 5 & 1 & 2 & 1 & 4 & 1 & 0 & 1 & 0 & 2 & 2 & 3 \\
\hline $\begin{array}{l}\text { San Luis } \\
\text { Obispo }\end{array}$ & 7 & 5 & 4 & 3 & 4 & 1 & 1 & 3 & 4 & 1 & 0 & 1 & 2 & 2 & 2 & 2 \\
\hline San Mateo & 10 & 6 & 8 & 5 & 2 & 3 & 1 & 5 & 3 & 1 & 1 & 1 & 1 & 2 & 4 & 1 \\
\hline $\begin{array}{l}\text { Santa } \\
\text { Barbara }\end{array}$ & 3 & 5 & 4 & 5 & 7 & 3 & 4 & 3 & 3 & 4 & 3 & 2 & 5 & 3 & 3 & 3 \\
\hline Santa Clara & 8 & 3 & 1 & 3 & 7 & 2 & 1 & 3 & 4 & 3 & 1 & 3 & 2 & 1 & 5 & 2 \\
\hline Santa Cruz & 6 & 3 & 3 & 5 & 5 & 2 & 2 & 2 & 4 & 1 & 1 & 0 & 2 & 2 & 4 & 1 \\
\hline Shasta & 1 & 0 & 4 & 3 & 1 & 1 & 1 & 3 & 3 & 2 & 0 & 2 & 0 & 2 & 2 & 1 \\
\hline Sierra & 3 & 1 & 5 & 4 & 1 & 4 & 1 & 2 & 2 & 1 & 0 & 1 & 1 & 3 & 2 & 1 \\
\hline Siskiyou & 3 & 3 & 3 & 3 & 1 & 2 & 0 & 2 & 5 & 1 & 0 & 0 & 2 & 3 & 2 & 1 \\
\hline Solano & 5 & 2 & 4 & 5 & 5 & 1 & 2 & 1 & 4 & 2 & 0 & 0 & 1 & 1 & 2 & 2 \\
\hline Sonoma & 7 & 5 & 6 & 5 & 4 & 2 & 1 & 1 & 1 & 2 & 0 & 0 & 1 & 2 & 3 & 1 \\
\hline Stanislaus & 4 & 3 & 6 & 3 & 4 & 1 & 1 & 2 & 4 & 2 & 0 & 0 & 2 & 1 & 2 & 2 \\
\hline
\end{tabular}


medRxiv preprint doi: https://doi.org/10.1101/2020.11.08.20224915; this version posted August 29, 2021. The copyright holder for this preprint (which was not certified by peer review) is the author/funder, who has granted medRxiv a license to display the preprint in perpetuity.

It is made available under a CC-BY-NC 4.0 International license .

\begin{tabular}{|l|l|l|l|l|l|l|l|l|l|l|l|l|l|l|l|l}
\hline Sutter & 2 & 1 & 3 & 2 & 4 & 1 & 1 & 2 & 4 & 3 & 0 & 0 & 1 & 2 & 3 & 1 \\
\hline Tehama & 2 & 0 & 3 & 3 & 1 & 2 & 1 & 2 & 2 & 2 & 0 & 0 & 1 & 1 & 4 & 1 \\
\hline Trinity & 6 & 1 & 7 & 3 & 1 & 1 & 0 & 2 & 5 & 1 & 0 & 2 & 1 & 1 & 3 & 1 \\
\hline Tulare & 6 & 3 & 6 & 4 & 4 & 1 & 1 & 1 & 2 & 1 & 0 & 0 & 1 & 2 & 2 & 2 \\
\hline Tuolumne & 4 & 3 & 5 & 4 & 2 & 2 & 2 & 1 & 4 & 2 & 0 & 0 & 2 & 1 & 2 & 1 \\
\hline Ventura & 4 & 3 & 5 & 5 & 5 & 3 & 1 & 2 & 4 & 1 & 0 & 0 & 1 & 2 & 2 & 2 \\
\hline Yolo & 3 & 3 & 6 & 4 & 7 & 1 & 2 & 2 & 3 & 3 & 0 & 2 & 4 & 2 & 3 & 1 \\
\hline Yuba & 2 & 1 & 3 & 2 & 4 & 1 & 1 & 2 & 4 & 3 & 0 & 0 & 1 & 1 & 3 & 1 \\
\hline
\end{tabular}

Daily rates of public health order/topic stricture by county: We employed graphical analysis to characterize the timing and relative degree of stricture of each county's orders related to each of the 16 topics. Additionally, we employed graphical analysis to characterize the relative degree of stricture within California regions. One particularly interesting feature that varies across counties is the use of face masking orders and the use of closure orders in the late spring and summer. In many counties, closure order strictness increased prior to masking order strictness. However, once masking order strictness increased, some counties appear to have moved to re-open while others maintained or increased closure strictness. The use of different order types as substitutes for one another or as complements is an important area for further research.

\section{Discussion and Conclusions}

Prior to vaccines, non-pharmaceutical interventions were the most widely used approach to controlling the spread of COVID-19 epidemics. Various jurisdictions implemented public health orders as a means of reducing effective contacts and controlling their local epidemics. While multiple studies have examined the effectiveness of various orders (e.g. use of face masks) for epidemic control [63-69], a complete picture of the magnitude and mechanisms of effectiveness of orders and regulation will likely require geographical and temporal variation in the contents of orders and their strictness. Current data sets tend to report on orders and regulations on a national and/or state level with current county-level efforts not necessarily standardized in their review and curation nor in their characterization of the topics and level of strictness contained in each order [70-72].

We constructed a county-level longitudinal data set of public health orders issues by California and its 58 counties pertaining to its 40 million residents. We observe both spatial and temporal patterns in the timing and strictness of orders on a variety of topics across counties and over time. We have made the dataset publicly available as part of our commitment to open data and combating the COVID-19 pandemic (http://sc-cosmo.org).

There are many potential uses of the data set we have constructed and released. It can be used in a variety of quasi-experimental designs to estimate the effects of such orders on epidemic health outcomes and on non-health outcomes (e.g., unemployment), potentially refining or extending prior studies in this area. It can be used to examine mechanisms like behavioral responses to such orders and compliance using either surveys such as those whose results are 
medRxiv preprint doi: https://doi.org/10.1101/2020.11.08.20224915; this version posted August 29, 2021. The copyright holder for this preprint (which was not certified by peer review) is the author/funder, who has granted medRxiv a license to display the preprint in perpetuity.

It is made available under a CC-BY-NC 4.0 International license .

made available by Facebook or measured behavioral responses like those made available by Google's Mobility Trends [73-74].

The approach we have employed for California is not exclusively applicable to California, and our hope is that other researchers in other jurisdictions may build up similar data sets and make them publicly available, leveraging the methods and approach we have taken. We are eager to assist in such efforts to the extent possible.

In conclusion, our data set provides an open source and useful contribution to analyses of important issues related to the COVID-19 pandemic. Its methods may be used more broadly to characterize policy responses. Illustrating its utility, a descriptive examination of public health orders at the county-level in California that accounts for the timing of the orders, the topics the orders address, and their level of strictness highlights intriguing patterns like the use of masking orders as a complement to other types of closures in some jurisdictions, presumably attempting to further reduce COVID-19 incidence, and as a substitute to other types of closure in other jurisdictions, presumably attempt to maintain COVID-19 at low incidence while mitigating the effects of health orders on the local economy. Further analyses of such phenomena are highly relevant and urgently needed as the pandemic continues. 
medRxiv preprint doi: https://doi.org/10.1101/2020.11.08.20224915; this version posted August 29, 2021. The copyright holder for this preprint (which was not certified by peer review) is the author/funder, who has granted medRxiv a license to display the preprint in perpetuity. It is made available under a CC-BY-NC 4.0 International license .

\section{References}

1. State of California. https://www.cdph.ca.gov/Programs/CID/DCDC/Pages/Guidance.aspx

2. Los Angeles. http://publichealth.lacounty.gov/media/Coronavirus/

3. San Diego. https://www.sandiegocounty.gov/content/sdc/hhsa/programs/phs/community_epidemiolo gy/dc/2019-nCoV/health-order.html

4. Orange. https://occovid19.ochealthinfo.com/article/oc-health-officers-ordersrecommendations

5. Riverside. https://www.rivcoph.org/Public-Health-Order-History

6. San Bernardino. https://sbcovid19.com/resources/\#health-officer-orders

7. Santa Clara. https://www.sccgov.org/sites/covid19/Pages/public-health-orders.aspx

8. Alameda. https://covid-19.acgov.org/sip.page

9. Sacramento. https://www.saccounty.net/COVID19/Pages/PublicHealthOrder_FAQs_Docs.aspx

10. Contra Costa. https://www.coronavirus.cchealth.org/health-orders

11. Fresno. https://www.co.fresno.ca.us/departments/public-health/covid-19/covid-19-orders

12. Kern. https://kernpublichealth.com/healthofficerorders/

13. San Francisco. https://www.sfdph.org/dph/alerts/coronavirus-healthorders.asp

14. Ventura. https://www.venturacountyrecovers.org/public-health-orders/

15. San Mateo. https://www.smchealth.org/coronavirus-health-officer-updates

16. San Joaquin. http://www.sjcphs.org/coronavirus.aspx

17. Stanislaus. http://schsa.org/corona-virus/ph-order/

18. Sonoma. https://socoemergency.org/emergency/novel-coronavirus/coronavirus-healthorders-guidance-archive/

19. Tulare. https://covid19.tularecounty.ca.gov/tulare-county-emergency-order-forprevention-of-covid19-transmission/

20. Solano. https://www.solanocounty.com/depts/ph/covid_19_health_order.asp

21. Santa Barbara. https://publichealthsbc.org/health-officer-orders/

22. Monterey. https://www.co.monterey.ca.us/government/departments-ah/health/diseases/2019-novel-coronavirus-2019-ncov/health-officer-shelter-in-place-order

23. Placer. https://www.placer.ca.gov/coronavirus/news

24. San Luis Obispo. https://www.emergencyslo.org/en/covid-status.aspx?_mid_=448

25. Merced. https://reopenmercedcounty.com/orders/

26. Santa Cruz. http://santacruzhealth.org/HSAHome/HSADivisions/PublicHealth/CommunicableDiseaseCo ntrol/Coronavirushome/Publiclnformation.aspx

27. Marin. https://coronavirus.marinhhs.org/updates?field_categories_target_id =17

28. Yolo. https://www.yolocounty.org/health-human-services/adults/communicable-diseaseinvestigation-and-control/novel-coronavirus-2019/shelter-inplace\#: :text=To\%20strengthen\%20this\%20effort\%20and,term\%20used\%20in\%20emergen cy\%20preparedness.

29. Butte. http://www.buttecounty.net/ph/Home/News 
medRxiv preprint doi: https://doi.org/10.1101/2020.11.08.20224915; this version posted August 29, 2021. The copyright holder for this preprint (which was not certified by peer review) is the author/funder, who has granted medRxiv a license to display the preprint in perpetuity. It is made available under a CC-BY-NC 4.0 International license .

30. El Dorado. https://edcgov.us/Government/hhsa/Pages/EDCCOVID-19-OrdersDirectives.aspx

31. Imperial. http://www.icphd.org/health-information-and-resources/healthy-facts/covid19/guidance-and-resources/state-\&-county-orders/

32. Shasta. https://www.co.shasta.ca.us/covid-19/news

33. Madera. https://www.maderacounty.com/government/public-health/corona-virus-covid19/covid-revised

34. Kings. https://www.countyofkings.com/departments/health-welfare/publichealth/coronavirus-disease-2019-covid-19/-fsiteid-1

35. Napa. https://www.countyofnapa.org/2739/Coronavirus

36. Humboldt. https://humboldtgov.org/2725/Local-Orders

37. Nevada. https://www.mynevadacounty.com/2924/Coronavirus

38. Sutter. https://www.suttercounty.org/doc/government/depts/cao/em/coronavirus

39. Mendocino. https://www.mendocinocounty.org/community/novel-coronavirus/healthorder

40. Yuba. https://www.yuba.org/coronavirus/HealthOrders.php

41. Tehama. https://www.tehamacohealthservices.net/order-of-the-tehama-county-healthofficer/

42. Lake. http://health.co.lake.ca.us/Coronavirus/press.htm

43. San Benito. https://hhsa.cosb.us/public-health/covid-19/

44. Tuolumne. https://www.tuolumnecounty.ca.gov/1290/Health-Officer-Orders

45. Calaveras. https://covid19.calaverasgov.us/\#gsc.tab=0

46. Siskiyou. https://www.co.siskiyou.ca.us/publichealth/page/public-health-order-siskiyoucounty-public-health-officer-posted-3162020

47. Amador. https://www.amadorgov.org/services/public-health/covid-19/emergencydeclarations-and-health-officer-orders

48. Lassen. https://lassencares.org/local-press-releases

49. Glenn. https://www.countyofglenn.net/dept/health-human-services/public-health/covid-19

50. Del Norte. http://www.co.del-norte.ca.us/departments/health-human-services/publichealth/health-safety-alerts

51. Colusa. http://www.countyofcolusa.org/771/COVID19

52. Plumas. https://www.plumascounty.us/2669/Novel-Coronavirus-2019-COVID-19

53. Inyo. https://www.inyocounty.us/covid-19/orders-directives

54. Mariposa. https://www.mariposacounty.org/2445/Health-Officer-Orders-and-PressReleases

55. Mono. https://coronavirus.monocounty.ca.gov/pages/directives

56. Trinity. https://www.trinitycounty.org/covid-19/public-health-advisories

57. Modoc. https://modochealthservices.org/corona-virus

58. Sierra. https://sierracounty.ca.gov/596/Press-Releases

59. Alpine. http://alpinecountyca.gov/Index.aspx?NID=516

60. The Wayback Machine. https://archive.org/web/

61. The COVID-19 US State Policy Database. https://docs.google.com/spreadsheets/d/1zu9qEWI8PsOI_i8nl_S29HDGHIlp2IfVMsGxpQ5tvAQ/edit \#gid=973655443 
medRxiv preprint doi: https://doi.org/10.1101/2020.11.08.20224915; this version posted August 29, 2021. The copyright holder for this preprint (which was not certified by peer review) is the author/funder, who has granted medRxiv a license to display the preprint in perpetuity.

It is made available under a CC-BY-NC 4.0 International license .

62. California's Blueprint for a Safer Economy. https://covid19.ca.gov/safer-economy/

63. Chernozhukov V, Kasahara H, Schrimpf P. Causal impact of masks, policies, behavior on early covid-19 pandemic in the U.S. J Econom. 2020 Oct 17.

64. Gallaway MS, Rigler J, Robinson S, Herrick K, Livar E, Komatsu KK, Brady S, Cunico J, Christ CM. Trends in COVID-19 Incidence After Implementation of Mitigation Measures - Arizona, January 22-August 7, 2020. MMWR Morb Mortal Wkly Rep. 2020 Oct 9;69(40):1460-1463.

65. Casares M, Khan H. The Timing and Intensity of Social Distancing to Flatten the COVID-19 Curve: The Case of Spain. Int J Environ Res Public Health. 2020 Oct 6;17(19):7283.

66. Goldstein ND, Suder JS. Application of state law in the public health emergency response to COVID-19: an example from Delaware in the United States. J Public Health Policy. 2020 Sep 28:1-9.

67. Betsch C, Korn L, Sprengholz P, Felgendreff L, Eitze S, Schmid P, Böhm R. Social and behavioral consequences of mask policies during the COVID-19 pandemic. Proc Natl Acad Sci U S A. 2020 Sep 8;117(36):21851-21853.

68. Dave D, Friedson Al, Matsuzawa K, Sabia JJ. When Do Shelter-in-Place Orders Fight COVID19 Best? Policy Heterogeneity Across States and Adoption Time. Econ Inq. 2020 Aug 3:10.1111/ecin.12944.

69. Lyu W, Wehby GL. Community Use Of Face Masks And COVID-19: Evidence From A Natural Experiment Of State Mandates In The US. Health Aff (Millwood). 2020 Aug;39(8):1419-1425.

70. Kaiser Family Foundation. State Data and Policy Actions to Address Coronavirus. https://www.kff.org/coronavirus-covid-19/issue-brief/state-data-and-policy-actions-toaddress-coronavirus/

71. U.S. Department of Health and Human Services. COVID-19 State and County Policy Orders. https://healthdata.gov/dataset/covid-19-state-and-county-policy-orders

72. Zheng, Q., Jones, F.K., Leavitt, S.V. et al. HIT-COVID, a global database tracking public health interventions to COVID-19. Sci Data 7, 286 (2020).

73. Facebook COVID-19 Symptom Survey. https://dataforgood.fb.com/docs/covid-19-symptomsurvey-request-for-data-access/

74. Google Community Mobility Reports. https://www.google.com/covid19/mobility/ 
medRxiv preprint doi: https://doi.org/10.1101/2020.11.08.20224915; this version posted August 29, 2021. The copyright holder for this preprint (which was not certified by peer review) is the author/funder, who has granted medRxiv a license to display the preprint in perpetuity.

It is made available under a CC-BY-NC 4.0 International license .

\section{Appendix \\ State- and County-Level COVID-19 Public Health Orders in California: Constructing a Dataset and Describing Their Timing, Content, and Stricture}

Jeremy D. Goldhaber-Fiebert (1), Alexander F. Holsinger (1,2), Erin Holsinger (1), Elizabeth Long (1) on behalf of the SC-COSMO Modeling Consortium

February 23, 2021

(1) Stanford Health Policy, Centers for Health Policy and Primary Care and Outcomes Research, Stanford University School of Medicine and the Freeman Spogli Institute of International Studies, Stanford, CA, USA

(2) University of Texas at Austin, Austin, TX, USA

Appendix Table 1: Details of released data files

\begin{tabular}{|c|c|}
\hline PH_Orders_long & $\begin{array}{l}\text { Contains the main data that is the result of scraping the web for } \\
\text { all county public health orders and state public health directives. } \\
\text { Based on review of the full text, the orders are each coded as to } \\
\text { which category(s) (e.g., masking, closures) they pertain to and } \\
\text { the ordinal relative level of stricture they represent. The file } \\
\text { contains the following columns: county, dt_PHO, order_value, } \\
\text { order_type. The variable county refers to one of } 58 \text { of } \\
\text { California's counties (without the trailing string "County"). The } \\
\text { variable order_type refers to the category of restriction referred } \\
\text { to in a public health order. The variable order_value refers to the } \\
\text { level of stricture for a particular order type in a particular } \\
\text { county. The variable dt_PHO refers to the date that the county } \\
\text { was at a particular level of stricture for a particular order type. } \\
\text { This data set does not directly show when the county put out } \\
\text { each of its order but changes in levels of order_value for order } \\
\text { type on consecutive days show when there was an order(s) } \\
\text { propagated. }\end{array}$ \\
\hline PH_Orders_order_type & $\begin{array}{l}\text { Contains slightly longer textual descriptions of the order types. It } \\
\text { can be joined with } \mathrm{PH} \text { _Orders_long using the order_type } \\
\text { column. }\end{array}$ \\
\hline PH_Orders_order_value & $\begin{array}{l}\text { Contains the meanings of the scales for order values in within } \\
\text { each order type. It can be joined with PH_Orders_order_type } \\
\text { using the order_type column or with the PH_Orders_long using } \\
\text { the order_type and order_value columns. }\end{array}$ \\
\hline PH_Orders_region & $\begin{array}{l}\text { Contains groupings of counties into regions based on CDPH } \\
\text { groupings for "Economic Regions". Can be found at: } \\
\text { calcat.covid19.ca.gov/cacovidmodels/ }\end{array}$ \\
\hline PH_Orders_statewide & $\begin{array}{l}\text { Contains information when state-wide public health orders came } \\
\text { into effect. It essentially shows which order type the state-wide }\end{array}$ \\
\hline
\end{tabular}




\begin{tabular}{|l|l|}
\hline & $\begin{array}{l}\text { order pertains to and the date on which it went into effect. It } \\
\text { also documents the order value that was mandated. Note } \\
\text { several important things. First, when the state produced tiers, } \\
\text { the value for some counties could differ from others depending } \\
\text { on the tiers they were in (hence in the order_value column for } \\
\text { the statewide file we see a set of values that correspond to the } \\
\text { state-mandated levels for each tier). Second, counties could opt } \\
\text { to remain stricter than the state's order level and hence county } \\
\text { values may be greater than these values. This is relevant both for } \\
\text { simple state-wide orders and for tiered orders. }\end{array}$ \\
\hline PH_Orders_linklist & $\begin{array}{l}\text { Contains url for each of the public health orders included in the } \\
\text { dataset, by county and date of order. }\end{array}$ \\
\hline
\end{tabular}




\begin{tabular}{|c|c|}
\hline County Name & County Public Health Website \\
\hline $\begin{array}{l}\text { State of } \\
\text { California }\end{array}$ & https://www.cdph.ca.gov/Programs/CID/DCDC/Pages/Guidance.aspx \\
\hline Los Angeles & http://publichealth.lacounty.gov/media/Coronavirus/ \\
\hline San Diego & https://www.sandiegocounty.gov/content/sdc/hhsa/programs/phs/community_epidemiology/dc/2019-nCoV/health-order.html \\
\hline Orange & https://occovid19.ochealthinfo.com/article/oc-health-officers-orders-recommendations \\
\hline Riverside & https://www.rivcoph.org/Public-Health-Order-History \\
\hline San Bernardino & https://sbcovid19.com/resources/\#health-officer-orders \\
\hline Santa Clara & https://www.sccgov.org/sites/covid19/Pages/public-health-orders.aspx \\
\hline Alameda & https://covid-19.acgov.org/sip.page \\
\hline Sacramento & https://www.saccounty.net/COVID-19/Pages/PublicHealthOrder_FAQs_Docs.aspx \\
\hline Contra Costa & https://www.coronavirus.cchealth.org/health-orders \\
\hline Fresno & https://www.co.fresno.ca.us/departments/public-health/covid-19/covid-19-orders \\
\hline Kern & https://kernpublichealth.com/healthofficerorders/ \\
\hline San Francisco & https://www.sfdph.org/dph/alerts/coronavirus-healthorders.asp \\
\hline Ventura & https://www.venturacountyrecovers.org/public-health-orders/ \\
\hline San Mateo & https://www.smchealth.org/coronavirus-health-officer-updates \\
\hline San Joaquin & http://www.sjcphs.org/coronavirus.aspx \\
\hline Stanislaus & http://schsa.org/corona-virus/ph-order/ \\
\hline Sonoma & https://socoemergency.org/emergency/novel-coronavirus/coronavirus-health-orders-guidance-archive/ \\
\hline Tulare & https://covid19.tularecounty.ca.gov/tulare-county-emergency-order-for-prevention-of-covid19-transmission/ \\
\hline Solano & https://www.solanocounty.com/depts/ph/covid_19_health_order.asp \\
\hline Santa Barbara & https://publichealthsbc.org/health-officer-orders/ \\
\hline Monterey & https://www.co.monterey.ca.us/government/departments-a-h/health/diseases/2019-novel-coronavirus-2019-ncov/health-officer-shelter-in-place-order \\
\hline Placer & https://www.placer.ca.gov/coronavirus/news \\
\hline San Luis Obispo & https://www.emergencyslo.org/en/covid-status.aspx?_mid_=448 \\
\hline Merced & https://reopenmercedcounty.com/orders/ \\
\hline Santa Cruz & http://santacruzhealth.org/HSAHome/HSADivisions/PublicHealth/CommunicableDiseaseControl/Coronavirushome/Publiclnformation.aspx \\
\hline Marin & https://coronavirus.marinhhs.org/updates?field_categories_target_id=17 \\
\hline Yolo & $\begin{array}{l}\text { https://www.yolocounty.org/health-human-services/adults/communicable-disease-investigation-and-control/novel-coronavirus-2019/shelter-in- } \\
\text { place\#: :text=To\%20strengthen\%20this\%20effort\%20and,term\%20used\%20in\%20emergency\%20preparedness. }\end{array}$ \\
\hline Butte & http://www.buttecounty.net/ph/Home/News \\
\hline El Dorado & https://edcgov.us/Government/hhsa/Pages/EDCCOVID-19-Orders-Directives.aspx \\
\hline Imperial & http://www.icphd.org/health-information-and-resources/healthy-facts/covid-19/guidance-and-resources/state-\&-county-orders/ \\
\hline Shasta & https://www.co.shasta.ca.us/covid-19/news \\
\hline Madera & https://www.maderacounty.com/government/public-health/corona-virus-covid-19/covid-revised \\
\hline Kings & https://www.countyofkings.com/departments/health-welfare/public-health/coronavirus-disease-2019-covid-19/-fsiteid-1 \\
\hline Napa & https://www.countyofnapa.org/2739/Coronavirus \\
\hline
\end{tabular}




\begin{tabular}{|c|c|}
\hline Humboldt & https://humboldtgov.org/2725/Local-Orders \\
\hline Nevada & https://www.mynevadacounty.com/2924/Coronavirus \\
\hline Sutter & https://www.suttercounty.org/doc/government/depts/cao/em/coronavirus \\
\hline Mendocino & https://www.mendocinocounty.org/community/novel-coronavirus/health-order \\
\hline Yuba & https://www.yuba.org/coronavirus/HealthOrders.php \\
\hline Tehama & https://www.tehamacohealthservices.net/order-of-the-tehama-county-health-officer/ \\
\hline Lake & http://health.co.lake.ca.us/Coronavirus/press.htm \\
\hline San Benito & https://hhsa.cosb.us/public-health/covid-19/ \\
\hline Tuolumne & https://www.tuolumnecounty.ca.gov/1290/Health-Officer-Orders \\
\hline Calaveras & https://covid19.calaverasgov.us/\#gsc.tab=0 \\
\hline Siskiyou & https://www.co.siskiyou.ca.us/publichealth/page/public-health-order-siskiyou-county-public-health-officer-posted-3162020 \\
\hline Amador & https://www.amadorgov.org/services/public-health/covid-19/emergency-declarations-and-health-officer-orders \\
\hline Lassen & https://lassencares.org/local-press-releases \\
\hline Glenn & https://www.countyofglenn.net/dept/health-human-services/public-health/covid-19 \\
\hline Del Norte & http://www.co.del-norte.ca.us/departments/health-human-services/public-health/health-safety-alerts \\
\hline Colusa & http://www.countyofcolusa.org/771/COVID19 \\
\hline Plumas & https://www.plumascounty.us/2669/Novel-Coronavirus-2019-COVID-19 \\
\hline Inyo & https://www.inyocounty.us/covid-19/orders-directives \\
\hline Mariposa & https://www.mariposacounty.org/2445/Health-Officer-Orders-and-Press-Releases \\
\hline Mono & https://coronavirus.monocounty.ca.gov/pages/directives \\
\hline Trinity & https://www.trinitycounty.org/covid-19/public-health-advisories \\
\hline Modoc & https://modochealthservices.org/corona-virus \\
\hline Sierra & https://sierracounty.ca.gov/596/Press-Releases \\
\hline Alpine & http://alpinecountyca.gov/Index.aspx?NID=516 \\
\hline
\end{tabular}


Appendix Table 3. Additional websites accessed for county and state public health orders

The list of each public health order accessed and its URL link are now provided as a CSV file with the public data releases. For more information on the structure of the file, see Appendix Table 1. 
medRxiv preprint doi: https://doi.org/10.1101/2020.11.08.20224915; this version posted August 29, 2021. The copyright holder for this preprint (which was not certified by peer review) is the author/funder, who has granted medRxiv a license to display the preprint in perpetuity.

It is made available under a CC-BY-NC 4.0 International license .

Appendix Table 4: List of topics covered with definition

\begin{tabular}{|c|c|}
\hline Topic & Description \\
\hline State of Emergency & Binary variable for if state of emergency declared \\
\hline $\begin{array}{l}\text { Moratorium on Gatherings (pre- } \\
\text { vaccination) }\end{array}$ & $\begin{array}{l}\text { Ordinal variable of 1-10 signifying the stricture of } \\
\text { moratoriums on organized or public gatherings. } \\
\text { (Restrictions on household gatherings are covered with } \\
\text { the "Social bubbles" variable.) Note - restrictions on } \\
\text { gatherings were initially rolled into reopening orders, } \\
\text { therefore this variable was set to missing once a county } \\
\text { reached an initial reopening level of } 5 \text {. }\end{array}$ \\
\hline $\begin{array}{l}\text { Moratorium on Gatherings for } \\
\text { unvaccinated individuals }\end{array}$ & $\begin{array}{l}\text { Ordinal variable of 1-10 signifying the stricture of } \\
\text { organized or public gatherings. This variable was } \\
\text { reintroduced in the June 7th release to account for new } \\
\text { orders around the widespread reopening in the spring } \\
\text { of } 2021 \text { and adjusted to apply to only unvaccinated } \\
\text { individuals. }\end{array}$ \\
\hline $\begin{array}{l}\text { Moratorium on Gatherings for fully } \\
\text { vaccinated individuals }\end{array}$ & $\begin{array}{l}\text { Ordinal variable of 1-10 signifying the stricture of } \\
\text { organized or public gatherings for fully vaccinated } \\
\text { individuals. This variable was introduced in the June 7th } \\
\text { release. }\end{array}$ \\
\hline $\begin{array}{l}\text { Private Event Restrictions for } \\
\text { unvaccinated individuals }\end{array}$ & $\begin{array}{l}\text { Ordinal variable of 3-9 signifying the stricture of } \\
\text { organized private events for unvaccinated individuals. } \\
\text { This variable was introduced in the June } 7 \text { th release. }\end{array}$ \\
\hline $\begin{array}{l}\text { Private Event Restrictions for fully } \\
\text { vaccinated individuals }\end{array}$ & $\begin{array}{l}\text { Ordinal variable of 3-9 signifying the stricture of } \\
\text { organized private events for fully vaccinated } \\
\text { individuals. This variable was introduced in the June } 7 \text { th } \\
\text { release. }\end{array}$ \\
\hline Physical Distance Closures & $\begin{array}{l}\text { Ordinal variable of 1-10 signifying the stricture of } \\
\text { physical distance closures }\end{array}$ \\
\hline Stay at Home orders & $\begin{array}{l}\text { Ordinal variable with values of } 3,4,8 \text {, and } 10 \text { signifying } \\
\text { the stricture of stay-at-home orders }\end{array}$ \\
\hline $\begin{array}{l}\text { Quarantine for unvaccinated } \\
\text { residents }\end{array}$ & $\begin{array}{l}\text { Ordinal variable of 1-10 signifying the stricture of } \\
\text { quarantine for residents (Previous to the May 3rd } \\
\text { release, this variable applied to all individuals.) }\end{array}$ \\
\hline $\begin{array}{l}\text { Quarantine for fully vaccinated } \\
\text { residents }\end{array}$ & $\begin{array}{l}\text { Value of } 0 \text { signifying the CDC-linked guidance that fully } \\
\text { vaccinated individuals do not need to quarantine. This } \\
\text { variable was added in the May 3rd data release and all } \\
\text { orders from previous months were reviewed and } \\
\text { backcoded to reflect this new variable. }\end{array}$ \\
\hline $\begin{array}{l}\text { Quarantine for unvaccinated out- } \\
\text { of-state visitors }\end{array}$ & $\begin{array}{l}\text { Ordinal variable of } 1-8 \text { signifying the stricture of } \\
\text { quarantine for out-of-state visitors. (Previous to the } \\
\text { May } 3^{\text {rd }} \text { release, this variable applied to all individuals.) }\end{array}$ \\
\hline Quarantine for fully vaccinated & Value of 0 signifying the CDC-linked guidance that fully \\
\hline
\end{tabular}


medRxiv preprint doi: https://doi.org/10.1101/2020.11.08.20224915; this version posted August 29, 2021. The copyright holder for this preprint (which was not certified by peer review) is the author/funder, who has granted medRxiv a license to display the preprint in perpetuity.

It is made available under a CC-BY-NC 4.0 International license .

\begin{tabular}{|c|c|}
\hline out-of-state visitors & $\begin{array}{l}\text { vaccinated individuals do not need to quarantine. This } \\
\text { variable was added in the May } 3 \text { rd data release and all } \\
\text { orders from previous months were reviewed and } \\
\text { backcoded to reflect this new variable. }\end{array}$ \\
\hline Reopening & $\begin{array}{l}\text { Ordinal variable of }-1 \text { to }-9 \text { signifying the stricture of } \\
\text { reopening variables, with }-1 \text { being the lowest level of } \\
\text { reopening and }-9 \text { being the most reopening }\end{array}$ \\
\hline Second closures & $\begin{array}{l}\text { Ordinal variable of 1-10 signifying the stricture of } \\
\text { second closures }\end{array}$ \\
\hline Overall closure & $\begin{array}{l}\text { Prior to the introduction of the state tier system, a } \\
\text { composite variable of physical distance closures, } \\
\text { reopening, and second closures. Beginning on } 31 \\
\text { August this variable represented the tier assigned by } \\
\text { the state. }\end{array}$ \\
\hline Lab reporting and Contact tracing & $\begin{array}{l}\text { Ordinal variable of 1-9 signifying the stricture of lab } \\
\text { reporting and contact tracing requirements }\end{array}$ \\
\hline $\begin{array}{l}\text { Face masks for unvaccinated } \\
\text { individuals }\end{array}$ & $\begin{array}{l}\text { Ordinal variable of 1-10 signifying the stricture of face } \\
\text { mask orders. For the June } 7 \text { th release this variable was } \\
\text { updated to only apply to unvaccinated individuals. }\end{array}$ \\
\hline $\begin{array}{l}\text { Face masks for fully vaccinated } \\
\text { individuals }\end{array}$ & $\begin{array}{l}\text { Ordinal variable of } 1-10 \text { signifying the stricture of face } \\
\text { mask orders for fully vaccinated individuals. This } \\
\text { variable was introduced in the June } 7 \text { th release. }\end{array}$ \\
\hline $\begin{array}{l}\text { Social bubbles for unvaccinated } \\
\text { households }\end{array}$ & $\begin{array}{l}\text { Ordinal variable of } 2-9 \text { signifying the number of } \\
\text { individuals and external households a household can } \\
\text { interact with. This variable was added in the November } \\
\text { 30th data release and all orders from previous months } \\
\text { were reviewed and backcoded to reflect this new } \\
\text { variable. For the May 3rd release, this variable was } \\
\text { updated to only apply to unvaccinated households and } \\
\text { updated with .5 options for each value to reflect orders } \\
\text { that allowed extended/larger social bubbles with } \\
\text { vaccinated households. So if the value of social bubble } \\
\text { is } 3 \text { for unvaccinated individuals/households but } 1 \\
\text { household of unvaccinated is also allowed to join that } \\
\text { size gathering, the value for this order become a } 2.5 \text {. }\end{array}$ \\
\hline $\begin{array}{l}\text { Social bubbles for fully vaccinated } \\
\text { households }\end{array}$ & $\begin{array}{l}\text { Value of } 1 \text { based on CDC guidance on how vaccinated } \\
\text { households can socialize. This variable was added in the } \\
\text { May 3rd data release and all orders from previous } \\
\text { months were reviewed and backcoded to reflect this } \\
\text { new variable. }\end{array}$ \\
\hline Alcohol and Firearms & $\begin{array}{l}\text { Binary variable signifying if the order related to alcohol } \\
\text { or firearms }\end{array}$ \\
\hline Housing & Binary variable signifying if the order related to housing \\
\hline
\end{tabular}


medRxiv preprint doi: https://doi.org/10.1101/2020.11.08.20224915; this version posted August 29, 2021. The copyright holder for this preprint (which was not certified by peer review) is the author/funder, who has granted medRxiv a license to display the preprint in perpetuity.

It is made available under a CC-BY-NC 4.0 International license .

\begin{tabular}{|l|l|}
\hline Unemployment programs & $\begin{array}{l}\text { Binary variable signifying if the order related to } \\
\text { unemployment programs }\end{array}$ \\
\hline Food security & $\begin{array}{l}\text { Binary variable signifying if the order related to food } \\
\text { security }\end{array}$ \\
\hline Healthcare delivery & $\begin{array}{l}\text { Binary variable signifying if the order related to } \\
\text { healthcare delivery }\end{array}$ \\
\hline Racial disparities & $\begin{array}{l}\text { Binary variable signifying if the order related to racial } \\
\text { disparities }\end{array}$ \\
\hline Incarcerated individuals & $\begin{array}{l}\text { Binary variable signifying if the order related to } \\
\text { incarcerated individuals }\end{array}$ \\
\hline Substance use disorder policies & $\begin{array}{l}\text { Binary variable signifying if the order related to } \\
\text { substance use disorder policies }\end{array}$ \\
\hline
\end{tabular}


medRxiv preprint doi: https://doi.org/10.1101/2020.11.08.20224915; this version posted August 29, 2021. The copyright holder for this preprint (which was not certified by peer review) is the author/funder, who has granted medRxiv a license to display the preprint in perpetuity.

It is made available under a CC-BY-NC 4.0 International license .

Appendix Table 5. Descriptions of value definitions for each ordinal public health order category

\begin{tabular}{|c|c|c|}
\hline Topic & Value & Description \\
\hline $\begin{array}{l}\text { Moratorium on } \\
\text { Gatherings for } \\
\text { unvaccinated } \\
\text { individuals }\end{array}$ & 1 & Gatherings of 1000 people or more \\
\hline $\begin{array}{l}\text { Moratorium on } \\
\text { Gatherings for } \\
\text { unvaccinated } \\
\text { individuals }\end{array}$ & 5 & Gatherings of 500 or more \\
\hline $\begin{array}{l}\text { Moratorium on } \\
\text { Gatherings for } \\
\text { unvaccinated } \\
\text { individuals }\end{array}$ & 6 & Gatherings of 250 or more \\
\hline $\begin{array}{l}\text { Moratorium on } \\
\text { Gatherings for } \\
\text { unvaccinated } \\
\text { individuals }\end{array}$ & 7 & Gatherings of 100 or more \\
\hline $\begin{array}{l}\text { Moratorium on } \\
\text { Gatherings for } \\
\text { unvaccinated } \\
\text { individuals }\end{array}$ & 8 & Gatherings of 50 or more \\
\hline $\begin{array}{l}\text { Moratorium on } \\
\text { Gatherings for } \\
\text { unvaccinated } \\
\text { individuals }\end{array}$ & 9 & Gatherings of 25 or more \\
\hline $\begin{array}{l}\text { Moratorium on } \\
\text { Gatherings for } \\
\text { unvaccinated } \\
\text { individuals }\end{array}$ & 10 & Gatherings of 10 or more \\
\hline $\begin{array}{l}\text { Moratorium on } \\
\text { Gatherings for fully } \\
\text { vaccinated } \\
\text { individuals }\end{array}$ & 1 & Gatherings of 1000 people or more \\
\hline $\begin{array}{l}\text { Moratorium on } \\
\text { Gatherings for fully } \\
\text { vaccinated } \\
\text { individuals }\end{array}$ & 5 & Gatherings of 500 or more \\
\hline $\begin{array}{l}\text { Moratorium on } \\
\text { Gatherings for fully } \\
\text { vaccinated } \\
\text { individuals }\end{array}$ & 6 & Gatherings of 250 or more \\
\hline Moratorium on & 7 & Gatherings of 100 or more \\
\hline
\end{tabular}


medRxiv preprint doi: https://doi.org/10.1101/2020.11.08.20224915; this version posted August 29, 2021. The copyright holder for this preprint (which was not certified by peer review) is the author/funder, who has granted medRxiv a license to display the preprint in perpetuity.

It is made available under a CC-BY-NC 4.0 International license .

\begin{tabular}{|c|c|c|}
\hline $\begin{array}{l}\text { Gatherings for fully } \\
\text { vaccinated } \\
\text { individuals }\end{array}$ & & \\
\hline $\begin{array}{l}\text { Moratorium on } \\
\text { Gatherings for fully } \\
\text { vaccinated } \\
\text { individuals }\end{array}$ & 8 & Gatherings of 50 or more \\
\hline $\begin{array}{l}\text { Moratorium on } \\
\text { Gatherings for fully } \\
\text { vaccinated } \\
\text { individuals }\end{array}$ & 9 & Gatherings of 25 or more \\
\hline $\begin{array}{l}\text { Moratorium on } \\
\text { Gatherings for fully } \\
\text { vaccinated } \\
\text { individuals }\end{array}$ & 10 & Gatherings of 10 or more \\
\hline $\begin{array}{l}\text { Private Events for } \\
\text { unvaccinated } \\
\text { individuals }\end{array}$ & 3 & Outdoor capacity 400 people, Indoor capacity 200 people \\
\hline $\begin{array}{l}\text { Private Events for } \\
\text { unvaccinated } \\
\text { individuals }\end{array}$ & 4 & Outdoor capacity 300 people, Indoor capacity 150 people \\
\hline $\begin{array}{l}\text { Private Events for } \\
\text { unvaccinated } \\
\text { individuals }\end{array}$ & 5 & $\begin{array}{l}\text { Outdoor capacity } 200 \text { people, with or without indoor capacity } 100 \\
\text { people }\end{array}$ \\
\hline $\begin{array}{l}\text { Private Events for } \\
\text { unvaccinated } \\
\text { individuals }\end{array}$ & 6 & Outdoor capacity 100 people \\
\hline $\begin{array}{l}\text { Private Events for } \\
\text { unvaccinated } \\
\text { individuals }\end{array}$ & 7 & Outdoor capacity 50 people \\
\hline $\begin{array}{l}\text { Private Events for } \\
\text { unvaccinated } \\
\text { individuals }\end{array}$ & 9 & Only outdoors, capacity 25 people \\
\hline $\begin{array}{l}\text { Private Events for } \\
\text { fully vaccinated } \\
\text { individuals }\end{array}$ & 3 & Outdoor capacity 400 people, Indoor capacity 200 people \\
\hline $\begin{array}{l}\text { Private Events for } \\
\text { fully vaccinated } \\
\text { individuals }\end{array}$ & 4 & Outdoor capacity 300 people, Indoor capacity 150 people \\
\hline $\begin{array}{l}\text { Private Events for } \\
\text { fully vaccinated } \\
\text { individuals }\end{array}$ & 5 & $\begin{array}{l}\text { Outdoor capacity } 200 \text { people, with or without indoor capacity } 100 \\
\text { people }\end{array}$ \\
\hline Private Events for & 6 & Outdoor capacity 100 people \\
\hline
\end{tabular}


medRxiv preprint doi: https://doi.org/10.1101/2020.11.08.20224915; this version posted August 29, 2021. The copyright holder for this preprint (which was not certified by peer review) is the author/funder, who has granted medRxiv a license to display the preprint in perpetuity.

It is made available under a CC-BY-NC 4.0 International license .

\begin{tabular}{|c|c|c|}
\hline $\begin{array}{l}\text { fully vaccinated } \\
\text { individuals }\end{array}$ & & \\
\hline $\begin{array}{l}\text { Private Events for } \\
\text { fully vaccinated } \\
\text { individuals }\end{array}$ & 7 & Outdoor capacity 50 people \\
\hline $\begin{array}{l}\text { Private Events for } \\
\text { fully vaccinated } \\
\text { individuals }\end{array}$ & 9 & Only outdoors, capacity 25 people \\
\hline Stay at Home & 3 & Applies to those $>75$ yo or $>70$ yo with co-morbitities \\
\hline Stay at Home & 4 & Stay at home from $10 \mathrm{pm}-5 \mathrm{am}$ \\
\hline Stay at Home & 8 & Exemption for religious gatherings \\
\hline Stay at Home & 10 & All except essential workers must stay at home \\
\hline $\begin{array}{l}\text { Quarantine for } \\
\text { unvaccinated } \\
\text { residents }\end{array}$ & 1 & People with symptoms urged to self-isolate \\
\hline $\begin{array}{l}\text { Quarantine for } \\
\text { unvaccinated } \\
\text { residents }\end{array}$ & 2 & People should not return to work until 24 hours symptom-free \\
\hline $\begin{array}{l}\text { Quarantine for } \\
\text { unvaccinated } \\
\text { residents }\end{array}$ & 3 & If you have symptoms, isolate for 7 days or until 3 days fever-free \\
\hline $\begin{array}{l}\text { Quarantine for } \\
\text { unvaccinated } \\
\text { residents }\end{array}$ & 4 & If you are positive, isolate for 10 days and at least 1 day fever-free \\
\hline $\begin{array}{l}\text { Quarantine for } \\
\text { unvaccinated } \\
\text { residents }\end{array}$ & 5 & If you have been exposed, you must quarantine for 14 days \\
\hline $\begin{array}{l}\text { Quarantine for } \\
\text { unvaccinated } \\
\text { residents }\end{array}$ & 6 & Stay home if sick, quarantine for 14 days if exposed \\
\hline $\begin{array}{l}\text { Quarantine for } \\
\text { unvaccinated } \\
\text { residents }\end{array}$ & 7 & $\begin{array}{l}\text { If you have been exposed, quarantine for } 14 \text { days; sick must } \\
\text { isolate for } 7 \text { days from beg of symptoms and } 3 \text { days fever-free }\end{array}$ \\
\hline $\begin{array}{l}\text { Quarantine for } \\
\text { unvaccinated } \\
\text { residents }\end{array}$ & 8 & $\begin{array}{l}\text { If you have had any exposure to an individual with a positive test, } \\
\text { quarantine for } 14 \text { days; positive tests must isolate for } 10 \text { days; } \\
\text { symptomatic must isolate for at least } 10 \text { days from beg of } \\
\text { symptoms and } 1 \text { day fever-free }\end{array}$ \\
\hline $\begin{array}{l}\text { Quarantine for } \\
\text { unvaccinated } \\
\text { residents }\end{array}$ & 9 & $\begin{array}{l}\text { If you have had any exposure to an individual with a positive test, } \\
\text { quarantine for } 14 \text { days; positive tests must isolate for } 10 \text { days; } \\
\text { symptomatic must isolate for at least } 10 \text { days from beg of } \\
\text { symptoms and } 3 \text { days fever-free }\end{array}$ \\
\hline $\begin{array}{l}\text { Quarantine for } \\
\text { unvaccinated }\end{array}$ & 10 & Failure to comply with isolation can result in fine/misdemeanor \\
\hline
\end{tabular}


medRxiv preprint doi: https://doi.org/10.1101/2020.11.08.20224915; this version posted August 29, 2021. The copyright holder for this preprint (which was not certified by peer review) is the author/funder, who has granted medRxiv a license to display the preprint in perpetuity.

It is made available under a CC-BY-NC 4.0 International license .

\begin{tabular}{|c|c|c|}
\hline residents & & \\
\hline $\begin{array}{l}\text { Quarantine for } \\
\text { vaccinated } \\
\text { residents }\end{array}$ & 0 & $\begin{array}{l}\text { Fully vaccinated do not need to quarantine following exposure if } \\
\text { asymptomatic }\end{array}$ \\
\hline $\begin{array}{l}\text { Quarantine for } \\
\text { unvaccinated out- } \\
\text { of-state visitors }\end{array}$ & 1 & Exclude from events anyone from out-of-state with symptoms \\
\hline $\begin{array}{l}\text { Quarantine for } \\
\text { unvaccinated out- } \\
\text { of-state visitors }\end{array}$ & 2 & Exclude from events anyone who traveled from China \\
\hline $\begin{array}{l}\text { Quarantine for } \\
\text { unvaccinated out- } \\
\text { of-state visitors }\end{array}$ & 3 & $\begin{array}{l}\text { Exclude from events anyone with symptoms who traveled from } \\
\text { European or US hotspots }\end{array}$ \\
\hline $\begin{array}{l}\text { Quarantine for } \\
\text { unvaccinated out- } \\
\text { of-state visitors }\end{array}$ & 5 & $\begin{array}{l}\text { Require 14-day quarantine anyone who traveled from hotspots } \\
\text { out of county }\end{array}$ \\
\hline $\begin{array}{l}\text { Quarantine for } \\
\text { unvaccinated out- } \\
\text { of-state visitors }\end{array}$ & 6 & $\begin{array}{l}\text { No people may disembark from a cruise ship in which anyone has } \\
\text { been diagnosed with Covid without permission }\end{array}$ \\
\hline $\begin{array}{l}\text { Quarantine for } \\
\text { unvaccinated out- } \\
\text { of-state visitors }\end{array}$ & 7 & $\begin{array}{l}\text { Require 14-day quarantine for travelers coming from certain } \\
\text { states }\end{array}$ \\
\hline $\begin{array}{l}\text { Quarantine for } \\
\text { unvaccinated out- } \\
\text { of-state visitors }\end{array}$ & 8 & Require 14-day quarantine anyone coming from out of state \\
\hline $\begin{array}{l}\text { Quarantine for } \\
\text { out-of-state fully } \\
\text { vaccinated visitors }\end{array}$ & 0 & $\begin{array}{l}\text { Fully vaccinated do not need to quarantine following exposure if } \\
\text { asymptomatic }\end{array}$ \\
\hline $\begin{array}{l}\text { Lab reporting and } \\
\text { Contact tracing }\end{array}$ & 1 & Mandate reporting of positive tests \\
\hline $\begin{array}{l}\text { Lab reporting and } \\
\text { Contact tracing }\end{array}$ & 2 & Mandate reporting of all lab results \\
\hline $\begin{array}{l}\text { Lab reporting and } \\
\text { Contact tracing }\end{array}$ & 3 & $\begin{array}{l}\text { Allows those who "meet criteria" but without a doctor's order to } \\
\text { be tested by the County/ requires testing for all decedents }\end{array}$ \\
\hline $\begin{array}{l}\text { Lab reporting and } \\
\text { Contact tracing }\end{array}$ & 4 & $\begin{array}{l}\text { Require healthcare facilities to test any symptomatic, exposed or } \\
\text { at-risk persons }\end{array}$ \\
\hline $\begin{array}{l}\text { Lab reporting and } \\
\text { Contact tracing }\end{array}$ & 5 & Funds provided for contact tracing \\
\hline $\begin{array}{l}\text { Lab reporting and } \\
\text { Contact tracing }\end{array}$ & 6 & Public awareness for contact tracing provided \\
\hline $\begin{array}{l}\text { Lab reporting and } \\
\text { Contact tracing }\end{array}$ & 7 & $\begin{array}{l}\text { Businesses must req reporting of pos tests by personnel and then } \\
\text { must participate in contact tracing OR facilities must report all } \\
\text { febrile resp infections }\end{array}$ \\
\hline
\end{tabular}


medRxiv preprint doi: https://doi.org/10.1101/2020.11.08.20224915; this version posted August 29, 2021. The copyright holder for this preprint (which was not certified by peer review) is the author/funder, who has granted medRxiv a license to display the preprint in perpetuity.

It is made available under a CC-BY-NC 4.0 International license .

\begin{tabular}{|c|c|c|}
\hline $\begin{array}{l}\text { Lab reporting and } \\
\text { Contact tracing }\end{array}$ & 8 & $\begin{array}{l}\text { Residents and personnel of Residential Facilities must submit to } \\
\text { testing }\end{array}$ \\
\hline $\begin{array}{l}\text { Lab reporting and } \\
\text { Contact tracing }\end{array}$ & 9 & Business forced to test all employees to remain open \\
\hline $\begin{array}{l}\text { Face masks for } \\
\text { unvaccinated } \\
\text { individuals }\end{array}$ & 1 & Face coverings suggested for essential businesses \\
\hline $\begin{array}{l}\text { Face masks for } \\
\text { unvaccinated } \\
\text { individuals }\end{array}$ & 2 & Allow businesses to require face coverings \\
\hline $\begin{array}{l}\text { Face masks for } \\
\text { unvaccinated } \\
\text { individuals }\end{array}$ & 3 & $\begin{array}{l}\text { Face coverings required for those in public facing essential } \\
\text { businesses }\end{array}$ \\
\hline $\begin{array}{l}\text { Face masks for } \\
\text { unvaccinated } \\
\text { individuals }\end{array}$ & 4 & $\begin{array}{l}\text { Face coverings required for those in public facing essential } \\
\text { businesses and those who visit }\end{array}$ \\
\hline $\begin{array}{l}\text { Face masks for } \\
\text { unvaccinated } \\
\text { individuals }\end{array}$ & 5 & $\begin{array}{l}\text { Masks also required for those in nursing homes plus residents } \\
\text { when not in their rooms }\end{array}$ \\
\hline $\begin{array}{l}\text { Face masks for } \\
\text { unvaccinated } \\
\text { individuals }\end{array}$ & 6 & $\begin{array}{l}\text { Masks required when using public outdoor spaces, visiting } \\
\text { businesses, riding public transportation, for those over } 12 \text { yo }\end{array}$ \\
\hline $\begin{array}{l}\text { Face masks for } \\
\text { unvaccinated } \\
\text { individuals }\end{array}$ & 7 & Masks required for all people in public places \\
\hline $\begin{array}{l}\text { Face masks for } \\
\text { unvaccinated } \\
\text { individuals }\end{array}$ & 8 & $\begin{array}{l}\text { Mask mandate for anyone leaving their homes with possible } \\
\text { contact with non-household members, includes exercise when } \\
\text { one could come within } 30 \text { feet of others }\end{array}$ \\
\hline $\begin{array}{l}\text { Face masks for } \\
\text { unvaccinated } \\
\text { individuals }\end{array}$ & 9 & $\begin{array}{l}\text { Masks required for all individuals when in public spaces, } \\
\text { potentially enforceable. }\end{array}$ \\
\hline $\begin{array}{l}\text { Face masks for } \\
\text { unvaccinated } \\
\text { individuals }\end{array}$ & 10 & $\begin{array}{l}\text { Mask mandate for all public places, specifically enforced with } \\
\text { fines, charges }\end{array}$ \\
\hline $\begin{array}{l}\text { Face masks for } \\
\text { fully vaccinated } \\
\text { individuals }\end{array}$ & 4 & $\begin{array}{l}\text { Fully vaccinated people only need to wear masks indoors or if in } \\
\text { crowds outdoors }\end{array}$ \\
\hline Closures & 0 & $\begin{array}{l}\text { No closure, i.e. no restrictions (Value following end of tier system } \\
\text { on } 6 / 15 \text { ) }\end{array}$ \\
\hline Closures & 1 & $\begin{array}{l}\text { Lowest closure, e.g., gathering restrictions or wineries closed } \\
\text { (Yellow tier post 8/31) }\end{array}$ \\
\hline Closures & 2 & $\begin{array}{l}\text { Select recreation areas closed, e.g., beaches on weekends (Orange } \\
\text { tier post 8/31) }\end{array}$ \\
\hline
\end{tabular}


medRxiv preprint doi: https://doi.org/10.1101/2020.11.08.20224915; this version posted August 29, 2021. The copyright holder for this preprint (which was not certified by peer review) is the author/funder, who has granted medRxiv a license to display the preprint in perpetuity.

It is made available under a CC-BY-NC 4.0 International license .

\begin{tabular}{|c|c|c|}
\hline Closures & 3 & Indoor dining closed (Red tier post 8/31) \\
\hline Closures & 4 & Nail and hair salons closed (Purple tier post 9/22) \\
\hline Closures & 5 & Indoor malls closed (Purple tier from $8 / 31$ to $9 / 22$ ) \\
\hline Closures & 6 & Places of worship closed (Stricter than purple tier post 8/31) \\
\hline Closures & 7 & Strict closures, e.g., schools closed \\
\hline Closures & 8 & Strict closures, e.g., day camps closed \\
\hline Closures & 9 & Hotels closed \\
\hline Closures & 10 & Strictest closure, e.g., all businesses and recreation areas closed \\
\hline $\begin{array}{l}\text { Social bubbles for } \\
\text { unvaccinated } \\
\text { households }\end{array}$ & 1.2 & $\begin{array}{l}\text { Gatherings may be indoor or outdoor w capacity } 100 \mathrm{ppl} \text {, fully } \\
\text { vaccinated may gather indoors w/o masks }\end{array}$ \\
\hline $\begin{array}{l}\text { Social bubbles for } \\
\text { unvaccinated } \\
\text { households }\end{array}$ & 1.3 & $\begin{array}{l}\text { Gatherings may be indoor or outdoor w capacity } 50 \text { ppl, fully vaccinated } \\
\text { may gather indoors w/o masks }\end{array}$ \\
\hline $\begin{array}{l}\text { Social bubbles for } \\
\text { unvaccinated } \\
\text { households }\end{array}$ & 1.4 & $\begin{array}{l}\text { Gatherings may be indoor or outdoor w capacity } 25 \text { ppl, fully vaccinated } \\
\text { may gather indoors w/o masks }\end{array}$ \\
\hline $\begin{array}{l}\text { Social bubbles for } \\
\text { unvaccinated } \\
\text { households }\end{array}$ & 1.5 & $\begin{array}{l}\text { Corresponds to value of } 2 \text {, but with additional fully vaccinated } \\
\text { household }\end{array}$ \\
\hline $\begin{array}{l}\text { Social bubbles for } \\
\text { unvaccinated } \\
\text { households }\end{array}$ & 2 & $\begin{array}{l}\text { Gatherings of greater than } 3 \text { households are not allowed, must be } \\
\text { outside in purple tier }\end{array}$ \\
\hline $\begin{array}{l}\text { Social bubbles for } \\
\text { unvaccinated } \\
\text { households }\end{array}$ & 2.5 & $\begin{array}{l}\text { Corresponds to value of } 3 \text {, but with additional fully vaccinated } \\
\text { household }\end{array}$ \\
\hline $\begin{array}{l}\text { Social bubbles for } \\
\text { unvaccinated } \\
\text { households }\end{array}$ & 3 & $\begin{array}{l}\text { Gatherings of greater than } 3 \text { households are not allowed, must be } \\
\text { outside for all }\end{array}$ \\
\hline $\begin{array}{l}\text { Social bubbles for } \\
\text { unvaccinated } \\
\text { households }\end{array}$ & 4 & $\begin{array}{l}\text { Gatherings can only include } 3 \text { households, must be outside, must report } \\
\text { ill participants }\end{array}$ \\
\hline $\begin{array}{l}\text { Social bubbles for } \\
\text { unvaccinated } \\
\text { households }\end{array}$ & 5 & Gatherings can include 3 households, only 25 people \\
\hline $\begin{array}{l}\text { Social bubbles for } \\
\text { unvaccinated } \\
\text { households }\end{array}$ & 6 & $\begin{array}{l}\text { Gatherings must be outside \& limited to } 3 \text { hhds \& } 25 \mathrm{ppl} \text {; "meal" } \\
\text { gatherings should be limited to } 3 \text { hhds \& } 6 \mathrm{ppl}\end{array}$ \\
\hline $\begin{array}{l}\text { Social bubbles for } \\
\text { unvaccinated } \\
\text { households }\end{array}$ & 6.5 & $\begin{array}{l}\text { Corresponds to a value of } 7 \text {, but with additional fully vaccinated } \\
\text { household }\end{array}$ \\
\hline $\begin{array}{l}\text { Social bubbles for } \\
\text { unvaccinated }\end{array}$ & 7 & Gatherings shall be outside \& limited to 3 hhds \& 16 people \\
\hline
\end{tabular}


medRxiv preprint doi: https://doi.org/10.1101/2020.11.08.20224915; this version posted August 29, 2021. The copyright holder for this preprint (which was not certified by peer review) is the author/funder, who has granted medRxiv a license to display the preprint in perpetuity.

$$
\text { It is made available under a CC-BY-NC } 4.0 \text { International license. }
$$

\begin{tabular}{|c|c|c|}
\hline households & & \\
\hline $\begin{array}{l}\text { Social bubbles for } \\
\text { unvaccinated } \\
\text { households }\end{array}$ & 8 & $\begin{array}{l}\text { Households may not interact with other households between } 10 \mathrm{pm} \text { and } \\
5 \mathrm{am}\end{array}$ \\
\hline $\begin{array}{l}\text { Social bubbles for } \\
\text { unvaccinated } \\
\text { households }\end{array}$ & 9 & No gatherings of households allowed \\
\hline $\begin{array}{l}\text { Social bubbles for } \\
\text { vaccinated } \\
\text { households }\end{array}$ & 1 & $\begin{array}{l}\text { Fully vaccinated individuals can visit with other fully vaccinated } \\
\text { individuals indoors without wearing masks or physical distancing }\end{array}$ \\
\hline
\end{tabular}

